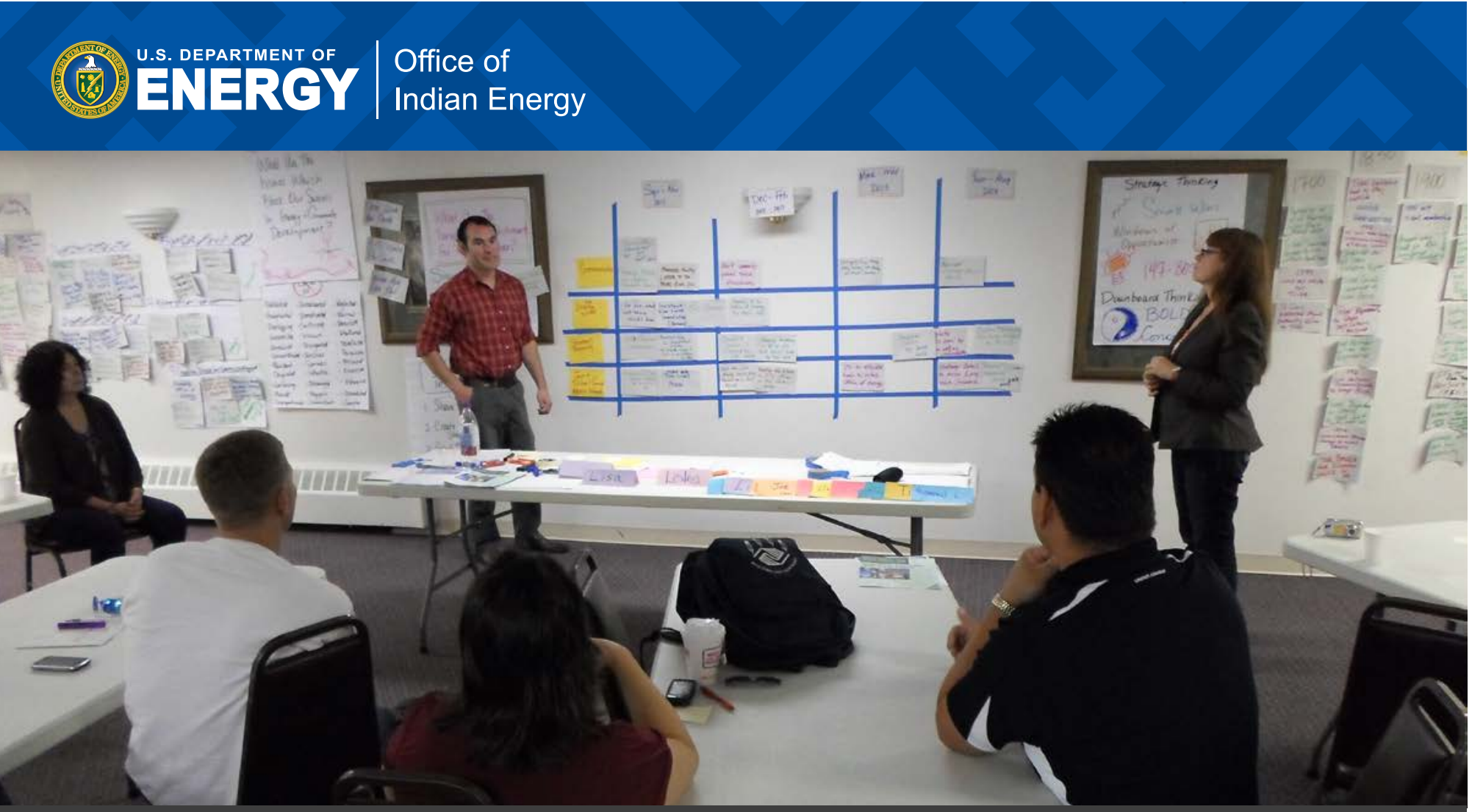

Engaging stakeholders and identifying priorities are critical to developing a strong energy vision and executing a successful project development plan.

\title{
ENERGY PROJECT DEVELOPMENT AND FINANCING STRATEGY FOR NATIVE ALASKA
}

The U.S. Department of Energy Office of Indian Energy Policy and Programs (DOE Office of Indian Energy) has developed a series of renewable energy project development and financing educational courses specifically for Tribes that:

- Provide a framework for tribal renewable energy project development and financing

- Set and manage project development expectations

- Identify decision points and the information needed to effectively make decisions

- Identify available tools for use in project development

- Provide examples of relevant projects.

Before developing a renewable energy project, it is critical that tribal leadership and staff understand the Tribe's prioritized goals for renewable energy projects and have a vision and plan in place to minimize risks. The DOE Office of Indian Energy's educational courses follow the project development cycle process shown here.

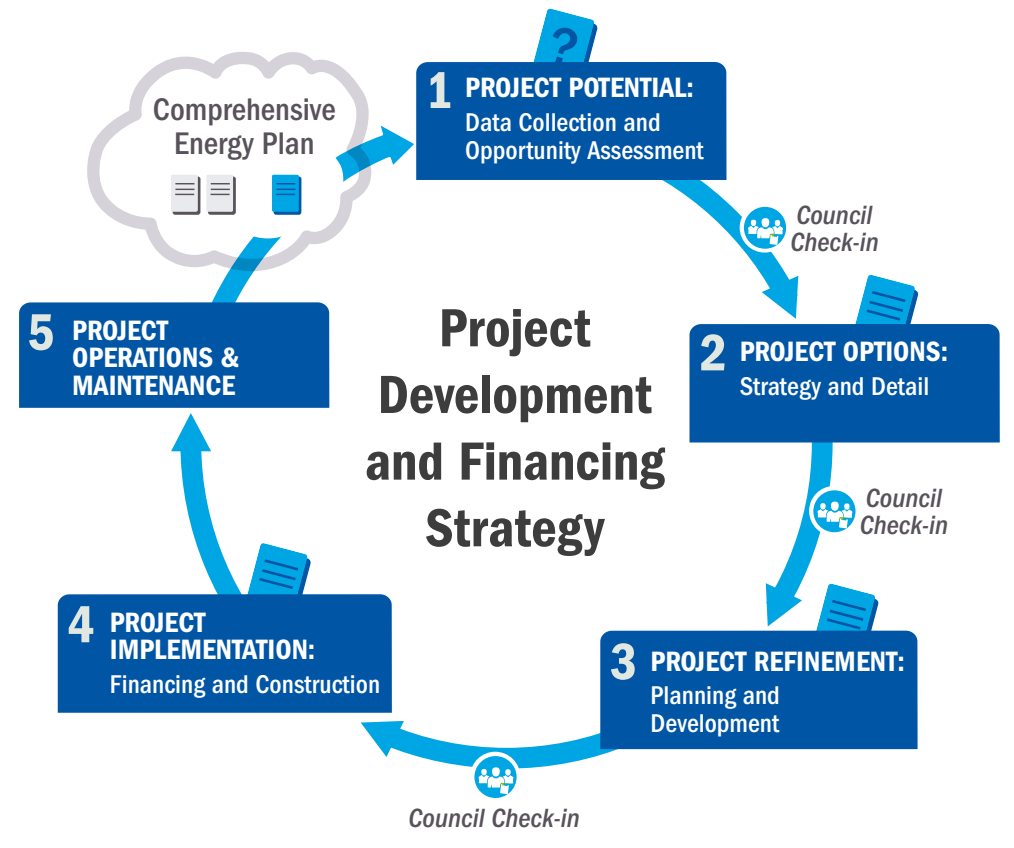




\section{Project Development Phases}

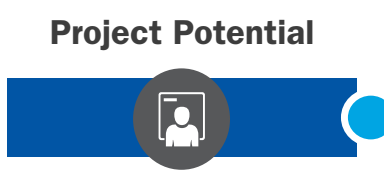

What is the potential for doing a project at a scale that meets my goals?

Data Collection and
Opportunity Assessment
Determine whether the project
is viable by evaluating:
- Possible sites for project
- Renewable energy
resource data
- Tribal facility electric cost
data, regulations, and inter-
connection requirements
- Potential markets and paths
to market for project power
and renewable sales
- Risks and utility rules.

Project Options

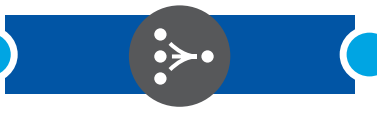

How do I interpret these options?

$$
\begin{aligned}
& \text { Strategy and Detail } \\
& \text { Narrow down the project } \\
& \text { options, including: } \\
& \text { - Final resource } \\
& \text { - Tribal role/ownership } \\
& \text { structure } \\
& \text { - Tax equity structure } \\
& \text { - Financing options } \\
& \text { - Procurement process } \\
& \text { - Permits. }
\end{aligned}
$$

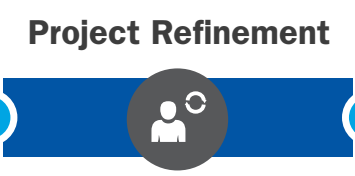

How do we get the specifics to our environment?

\section{Planning and Development}

Make decisions about:

- Ownership structure and project team

- Permitting (including environmental reviews) and interconnection agreement

- Technology, financing, and development costs

- Economics

- Vendors.

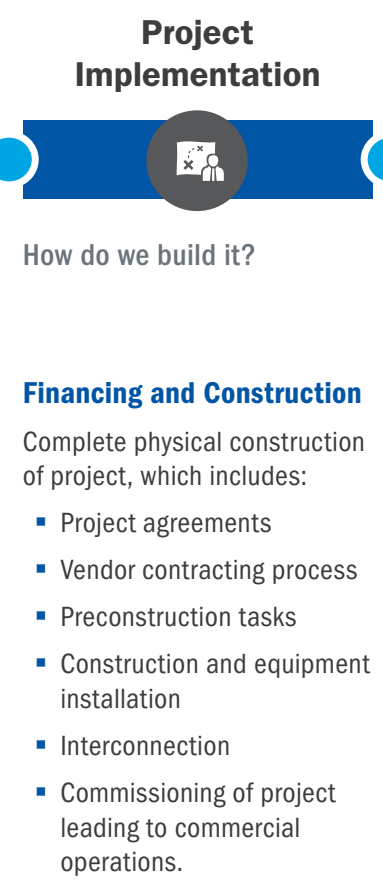

Project

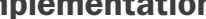

Project Operations \& Maintenance

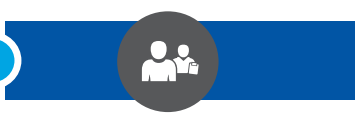

Who will maintain it once it is built?

Long-Term Management

Implement operations and maintenance plan that accounts for:

- Equipment maintenance and upkeep

- Inverter replacement

- Insurance

- Labor and staffing

- Extended warranty agreements.
Renewable Energy Curriculum and Technical Assistance for Tribes

The DOE Office of Indian Energy's educational courses provide an overview of renewable energy technologies, strategic energy planning, and renewable energy project development and financing. Access the free, on-demand webinars at www.nterlearning.org (search for "Indian Energy").

Alaska Native villages or regional and village corporations can apply to receive up to 40 hours of free technical assistance from DOE to help with strategic energy planning, project development, and finance. Apply online at energy.gov/ indianenergy/technical-assistance.

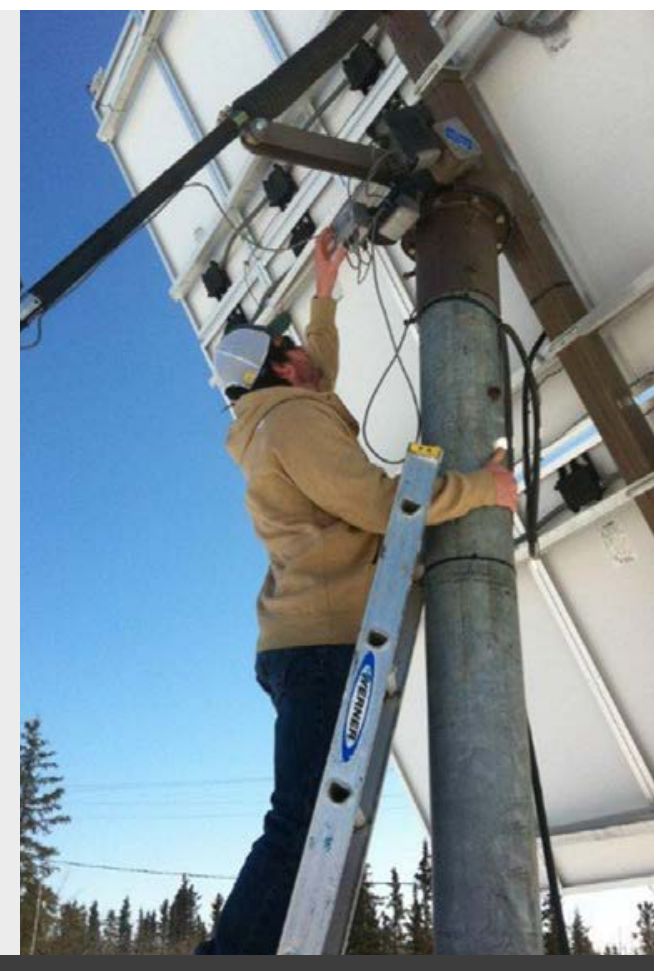

The National Renewable Energy Laboratory's Alex Dane helps repair the tracking motor of a community-owned solar photovoltaic array in Venetie, Alaska, as part of DOE Office of Indian Energy's Strategic Technical Assistance Response Team (START) Program.
2. U.S. DEPARTMENT OF (0) ENERGY

energy.gov/indianenergy indianenergy@hq.doe.gov

April $2014 \cdot$ DOE/IE-0034

Printed with a renewable-source ink on paper containing at least $50 \%$ wastepaper, including $10 \%$ post consumer waste.

Front page photo from Paul Dearhouse, NREL 24503; back page photo by Brian Hirsch, NREL 20893 